

\title{
Pengaruh Padat Tebar Berbeda Terhadap Pertumbuhan Benih Udang Windu (Penaeus Monodon Fabricius, 1798) Yang Dipelihara Pada Media Bioflok
}

\author{
Ilham Zulfahmi \\ Program Studi Biologi, Universitas Islam Negeri Ar-Raniry

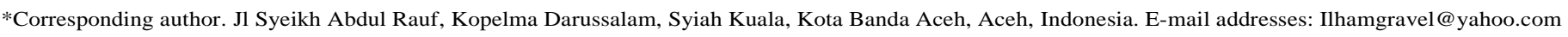

a r t i c 1 e i n f o

Article history:

Received 06 February 2017

Received in revised form 21 May

2017

Accepted 09 June 2017

Available online June 2017

Keywords:

biofloc

stocking density

ammonia

tiger shrimp

Kata Kunci:

bioflok

padat tebar

amoniak

udang windu

\section{a b s t r a c t}

This study aims to determine the optimal stocking density of tiger shrimp seed (Penaeus monodon) were maintained in media biofloc. This study uses a randomized complete design with four treatments and three replications ie, treatment A control (10 tiger shrimp seed / container without the addition bioflok), treatment B (10 tiger shrimp seed / container with the addition bioflok), treatment C (15 tiger shrimp seed / container with the addition bioflok), treatment D (tiger shrimp seed / container with the addition bioflok). The observed parameters include the specific growth rate (SGR), a daily increase of the absolute length and survival rate (SR) and feed efficiency. The results showed that the stocking density gives significantly effect to increase the daily increase of the absolute length, SGR and feed efficiency value of tiger prawn seed. Values length and SGR growth are highest in treatment $C$ respectively, $3.1 \pm 0.06 \mathrm{~cm}$ and $1.48 \pm 0.041 \% /$ day, meanwhile, the value of feed efficiency is highest in treatment D amounted to $47,43 \pm 7,26 \%$. There is no significant effect between the stocking density differences of each treatment on the survival of tiger shrimp juvenile Optimal maintenance toward stocking density for tiger shrimp seed using bioflok system is 15 tiger shrimp seed / 10 liters of water.

Penelitian ini bertujuan menentukan padat tebar optimal benih udang windu (Penaeus monodon) yang dipelihara dalam media bioflok. Penelitian ini menggunakan rancangan acak lengkap dengan empat perlakuan dan tiga ulangan yaitu, perlakuan A kontrol (10 ekor/wadah tanpa penambahan bioflok), perlakuan B (10 ekor/wadah dengan penambahan bioflok), perlakuan C (15 ekor/wadah dengan penambahan bioflok), perlakuan D (20 ekor/wadah dengan penambahan bioflok). Parameter yang diamati meliputi kelangsungan hidup (SR), Pertambahan Panjang Mutlak, Laju Pertumbuhan Spesifik (SGR) dan Efisiensi Pakan. Hasil penelitian menunjukkan bahwa perbedaan padat tebar berpengaruh nyata meningkatkan pertumbuhan panjang, SGR dan nilai efisiensi pakan benih udang windu. Nilai pertumbuhan panjang dan SGR tertinggi terdapat pada perlakuan C masing masing sebesar $3,1 \pm 0,06 \mathrm{~cm}$ dan $1,48 \pm 0,041 \% /$ hari, sedangkan nilai efesiensi pakan tertinggi terdapat pada perlakuan D sebesar $47,43 \pm 7,62 \%$. Tidak terdapat perbedaan yang nyata antara perbedaaan padat tebar tiap perlakuan terhadap kelangsungan hidup benih udah windu. Padat tebar optimal pemeliharaan benih udang windu dengan menggunakan sistem bioflok adalah 15 ekor/ 10 liter air.

\section{Pendahuluan}

Udang windu (Penaeus monodon Fabricius, 1798) adalah salah satu komoditas budidaya unggulan di Asia (FAO, 2008). Peluang usaha udang windu di Indonesia tergolong sangat baik, dengan nilai produksi pada tahun 2010 sebanyak 352.000 ton, dan meningkat menjadi 414.000 ton pada tahun 2012 (Kementerian Kelautan dan Perikanan, 2012). Kurangnya ketersediaan lahan menjadikan intensifikasi sebagai pilihan yang paling memungkinkan dalam meningkatkan produksi budidaya. Saat ini sistem budidaya masih terkendala berbagai permasalahan seperti pencemaran oleh limbah perikanan, penggunaan tepung ikan sebagai bahan baku pakan buatan serta penyebaran penyakit (FAO, 2008).

Teknologi bioflok merupakan salah satu teknologi alternatif baru di bidang budidaya guna mengatasi masalah kualitas air yang diadaptasi dari teknik pengolahan limbah domestik secara konvensional. Aplikasi bioflok mampu menurunkan kadar amonia dan nitrit dalam air serta berhasil meningkatkan efisiensi pemanfaatan nutrien. Teknik ini mentransformasi limbah budidaya secara langsung di dalam wadah budidaya dengan mempertahankan kecukupan oksigen, mikroorganisme dan rasio C/N dalam tingkat tertentu (Avnimelech, 2009).

Dalam sistem budidaya intensif, tingginya padat tebar akan berdampak pada meningkatnya input pakan yang dibutuhkan serta meningkatnya sisa metabolisme berupa nitrogen organik yang berpotensi mencemari perairan, oleh sebab itu dibutuhkan suatu teknologi ramah lingkungan untuk mengolah limbah agar mampu dimanfaatkan sebagai pakan tambahan bagi biota budidaya. Beberapa penelitian sebelumnya membuktikan bahwa aplikasi teknologi bioflok dapat meningkatkan 
kelangsungan hidup larva udang galah (Macrobrachium rosenbergii) dengan tingkat kelangsungan hidup terbaik diperoleh dengan menambahkan bioflok sebanyak $5 \mathrm{ml} /$ wadah (Asep et al., 2013). Aplikasi teknologi bioflok juga berhasil mempercepat pertumbuhan dan meningkatkan efisiensi pakan ikan lele pada media pemeliharaan (Abulias et al., 2014).

Optimimalisasi padat tebar merupakan salah satu langkah meningkatkan hasil budidaya. Prihantoro et al. (2014) menyebutkan bahwa padat tebar udang yang terlalu rendah akan menyebabkan produktivitas tambak berlebih yang ditandai dengan timbulnya ledakan populasi plankton. Sedangkan padat tebar yang melebihi daya dukung lahan dapat menyebabkan udang budidaya kesulitan mendapatkan ruang serta oksigen yang berdampak pada terhambatnya pertumbuhan. Penelitian ini bertujuan untuk menentukan padat tebar optimal benih udang windu (Peneaus mondon) yang dipelihara pada media bioflok .

\section{Metode Penelitian}

Penelitian ini dilaksanakan pada bulan Juni hingga Juli 2016. Pemeliharaan udang windu dilakukan di laboraturium Budidaya Perairan Universitas Almuslim Kabupaten Bireuen Provinsi Aceh, sedangkan analisis amoniak, nitrat dan nitrit dilakukan di PT. Sentral Proteinaprima, Bireuen.

Hewan uji yang digunakan berupa benih udang windu Post Larvae (PL) 21 sebanyak 500 ekor yang dikoleksi dari Desa Bungkah Kecamatan Muara Batu Kabupaten Aceh Utara. Proses sortir dilakukan untuk mendapatkan ukuran benih yang seragam. Sebelum diberi perlakuan, hewan uji terlebih dahulu diaklimatisasi selama 10 hari dalam aquarium berukuran $50 \times 30 \times 50 \mathrm{~cm}$ yang dilengkapi aerasi serta diberikan pakan komersil gold koin (kandungan protein 34\%, lemak 12\%, serat kasar 4\%, abu $12 \%$ dan kadar air 6\%) sebanyak dua kali sehari secara adlibitum.

Flok dikultur ke dalam wadah berbeda dengan volume 10 liter air payau bersalinitas 15-30 ppt. Air media disterilkan dengan menggunakan kaporit $30 \mathrm{mg} / \mathrm{L}$, serta diaerasi secara terus menerus untuk menjaga kecukupan oksigen terlarut. Setelah dianggap aman dari pengaruh kaporit, dimasukkan 3 gram pakan pelet sebagai unsur $\mathrm{N}$ yang sudah dihancurkan terlebih dahulu, kemudian ditambahkan probiotik yang mengandung bakteri Bacillus sp. sebanyak 5 mg/L, serta ditambahkan $5 \mathrm{~mL} / \mathrm{L}$ molase sebagai unsur C untuk selanjutnya dikultur selama sepuluh hari. Setelah flok terbentuk, dilakukan pengenceran dengan menambahkan sepuluh liter air payau bersalinitas 15-30 ppt ke dalam wadah, dan siap digunakan sebagai media pemeliharaan benih udang windu.

Benih udang windu dipelihara selama 30 hari. Selama pemeliharaan udang windu diberi pakan komersil dengan frekuensi pakan dua kali sehari sebanyak lima persen dari biomassa. Pemberian pakan dilakukan pada pukul 08.00 WIB dan pukul 17.00 WIB. Pengelolaan kualitas air dilakukan melalui penyiponan dan pergantian air sebanyak $30 \%$ dari total volume awal setiap 10 hari sekali.

Penelitian dilaksanakan secara eksperimental dengan menggunakan rancangan acak lengkap (RAL) dengan 4 perlakuan dan 3 ulangan terdiri dari perlakuan A kontrol (10 ekor/wadah tanpa penambahan bioflok), perlakuan B (10 ekor/wadah dengan penambahan bioflok), perlakuan C (15 ekor/wadah dengan penambahan bioflok), perlakuan D (20 ekor/wadah dengan penambahan bioflok). Pengamatan yang diamati pada akhir masa pemeliharaan meliputi tingkat kelangsungan hidup (SR), pertumbuhan panjang dan laju pertumbuhan spesifik (SGR) dan efisiensi pakan (EP). Tingkat kelangsungan hidup (SR) dihitung berdasarkan rumus Effendie (2002) yaitu:

$\mathrm{SR}=\frac{N t}{N 0} \times 100$

Keterangan: SR : Kelangsungan hidup udang (\%)

$\mathrm{Nt}$ : Jumlah udang yang hidup pada akhir penelitian (ekor)

No : Jumlah udang pada awal penelitian (ekor)

Pertumbuhan Panjang dihitung berdasarkant rumus Effendie (2002) yaitu:

$\mathrm{P}_{\mathrm{m}}=\mathrm{P}_{\mathrm{t}}-\mathrm{P}_{\mathrm{o}}$

Keterangan: $\quad \mathrm{P}_{\mathrm{m}}$ : Pertambahan panjang mutlak

$\mathrm{P}_{\mathrm{t}}$ : Panjang rata-rata individu hari ke $-\mathrm{t}(\mathrm{cm})$

$\mathrm{P}_{\mathrm{o}}$ : Panjang rata-rata individu hari $\mathrm{ke}-\mathrm{O}(\mathrm{cm})$

Laju Pertumbuhan Spesifik (SGR) dihitung berdasarkan rumus Effendie (2002) yaitu:

$\mathrm{SGR}=\left(t \sqrt{\frac{w t}{w o}}-1\right) \times 100$

Keterangan: SGR : Laju pertumbuhan rata-rata spesifik harian (\%/hari)

$t$ : Lama waktu pemeliharaan udang (hari)

Wo : Bobot rata-rata awal pemeliharaan udang $(\mathrm{mg})$

Wt : Bobot rata-rata akhir pemeliharaan udang (mg)

Nilai Efesiensi Pakan dihitung berdasarkan rumus Afrianto dan Evi (2005) yaitu:

$\mathrm{EP}=\frac{\left(\mathrm{W}_{\mathrm{t}}+\mathrm{D}_{0}\right)-\mathrm{W}_{0}}{\mathrm{~F}} \times 100$

Keterangan : EP : Efisiensi pakan $(\%)$

$\mathrm{Wt}$ : Bobot biomassa akhir penelitian $(\mathrm{g})$ 


\section{Wo : Bobot biomassa awal penelitian $(\mathrm{g})$ \\ D : Bobot benih yang mati $(\mathrm{g})$}

F : Jumlah pakan yang diberikan $(\mathrm{g})$

Pengukuran parameter fisik-kimiawi air pada media pemeliharaan dilakukan dilakukan secara in situ dan ex situ setiap 10 hari sekali meliputi suhu, salinitas oksigen terlarut, $\mathrm{pH}$, nitrat, nitrit dan amoniak. Pengukuran suhu dilakukan dengan menggunakan termometer, oksigen terlarut diukur dengan menggunakan dissolved oxygen meter, pH diukur dengan menggunakan $\mathrm{pH}$ meter, salinitas menggunakan refraktometer sedangkan amoniak, nitrat dan nitrit diukur dengan menggunakan metode spektrofotometrik. Analisis statistik yang digunakan untuk membandingkan, kelangsungan hidup (SR), pertumbuhan panjang, laju pertumbuhan spesifik (SGR), pertambahan panjang dan efesiensi pakan (EP) antar perlakuan adalah ANOVA (Analisys of Varians) satu arah dengan selang kepercayaan $95 \%$.

\section{Hasil dan Pembahasan}

Kelangsungan hidup benih udang windu tertinggi terdapat pada perlakuan B (10 ekor/wadah dengan perlakuan bioflok) dan perlakuan C (15 ekor/wadah dengan perlakuan bioflok) yaitu sebesar 86,66 $\pm 6,67 \%$ sedangkan tingkat kelangsungan hidup udang windu yang paling rendah terdapat pada perlakuan D (20 ekor/wadah dengan perlakuan bioflok) sebesar $76,66 \pm 5,77 \%$. Walaupun demikian, hasil uji stastistik menunjukkan bahwa tidak terdapat perbedaaan yang nyata antar perlakuan terhadap kelangsungan hidup benih udang windu $(\mathrm{p}>0,05)$.

Aplikasi bioflok berpengaruh nyata terhadap pertambahan panjang udang windu $(\mathrm{p}<0,05)$. Pertambahan panjang tertinggi terdapat pada perlakuan C (15 ekor/wadah dengan perlakuan bioflok) sebesar 3,1 $\pm 0,06 \mathrm{~cm}$ sedangkan pertambahan terendah

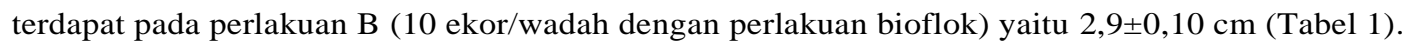

Tabel 1. Parameter Perlakuan Pada Setiap Perlakuan.

$$
\text { Variabel }
$$

Perlakuan

$$
\text { SR (\%) Pertambahan Panjang (cm) SGR }(\% / \text { hari }) \quad \text { EP }(\%)
$$

\begin{tabular}{lllll}
\hline A & $83,33 \pm 5,77$ & $3,0 \pm 0,10$ & $1,13 \pm 0,14$ & $37,26 \pm 6,08$ \\
B & $86,66 \pm 5,77$ & $2,9 \pm 0,10$ & $1,10 \pm 0,07$ & $34,10 \pm 5,76$ \\
C & $86,66 \pm 6,67$ & $3,1 \pm 0.06$ & $1,48 \pm 0,04$ & $40,46 \pm 8,17$ \\
D & $76,66 \pm 5,77$ & $3,0 \pm 0,06$ & $1,42 \pm 0,02$ & $47,43 \pm 7,62$ \\
\hline
\end{tabular}

Aplikasi bioflok juga memberikan pengaruh yang nyata terhadap laju pertumbuhan spesifik dan efisiensi pakan benih udang windu $(\mathrm{p}<0,05)$. Data pertambahan bobot pertumbuhan dalam pengamatan selama 30 hari masa pemeliharaan, tampak bahwa biomassa udang meningkat lebih cepat dengan laju pertumbuhan spesifik tertinggi terdapat pada perlakuan $\mathrm{C}$ (15

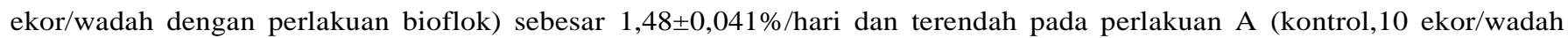
tanpa perlakuan bioflok) yaitu $1,13 \pm 0,045 \%$ /hari.

Tingginya pertumbuhan udang windu yang diberi perlakuan bioflok menunjukkan bahwa pakan yang diberikan dan dikonsumsi oleh udang sudah sesuai dengan diperlukan udang untuk pertumbuhan. Hasil evaluasi terhadap pertumbuhan udang windu menunjukkan bahwa efisiensi pakan tertinggi terdapat pada perlakuan D (20 ekor/wadah dengan perlakuan bioflok) sebesar 47,43 $\pm 7,62 \%$.

\section{Parameter fisik-kimiawi air}

Nilai parameter fisik kimiawi air pada setiap perlakuan selama masa penelitian masih berada dalam kisaran baik untuk pemeliharaan benih udang Windu. Kandungan oksigen terlarut dalam media pemeliharaan udang windu berkisar antara 4-5,3 $\mathrm{mg} / \mathrm{L}$ (Tabel 2). Konsentrasi amoniak, nitrat dan nitrit pada awal penelitian tidak menunjukkan nilai yang berbeda pada setiap perlakuan.

Tabel 2. Kisaran Nilai Parameter Fisik Kimiawi Air Pada Setiap Perlakuan

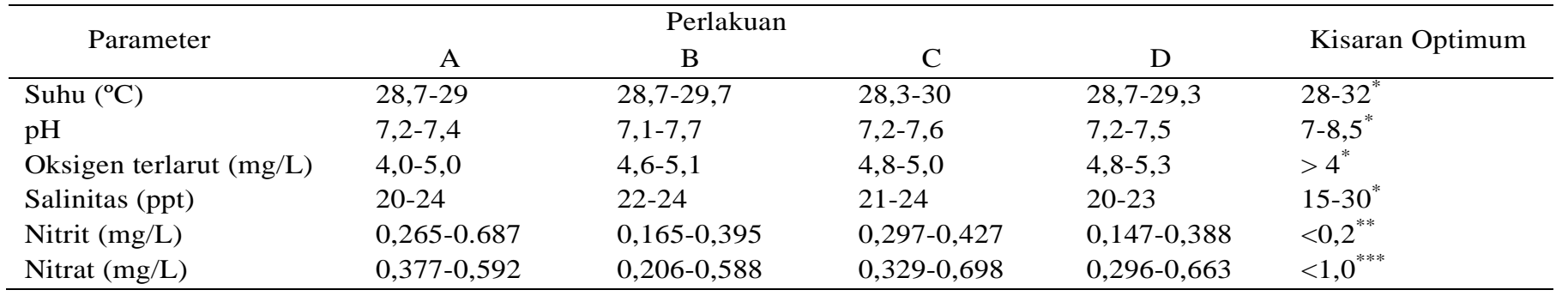

* SNI 01-6144-2006,** Taslihan et al. (2003), ***Fast \& Lester (1992)

Hasil pengamatan amoniak pada hari ke 10, nilai tertinggi terdapat pada perlakuan A (kontrol) yaitu $0,2625 \mathrm{mg} / \mathrm{L}$ dan nilai amonia terendah tardapat pada perlakuan B yaitu $0,1040 \mathrm{mg} / \mathrm{L}$. Pada akhir penelitian nilai, amonia tertinggi terdapat 
pada perlakuan A (kontrol) yaitu 0,2862 mg/L, dan nilai terendah terdapat pada perlakuan B yaitu 0,1772 mg/L. Nilai amonia diawal penelitian cenderung tinggi namun pada perlakuan yang menggunakan aplikasi bioflok, nilai amonia cenderung menurun dan lebih stabil (Gambar 1).



Gambar 1. Kandungan Amoniak Pada Setiap Perlakuan Selama Masa Pemeliharaan

Aplikasi teknologi bioflok pada setiap perlakuan tidak menunjukkan perbedaan signifikan terhadap kelangsungan hidup benih udang windu. Nilai tertinggi kelangsungan hidup di peroleh pada perlakuan B (10 ekor/wadah dengan perlakuan bioflok) yaitu sebesar $86,66 \%$. Hal ini menunjukkan adanya reaksi positif dari udang terhadap keberadaan flok dan pakan. Selain dari faktor lingkungan seperti suhu, $\mathrm{pH}$, oksigen terlarut dan salinitas, perkembangan flok yang baik akan mempengaruhi tingkat kelangsungan hidup udang. Kematian pada udang diduga akibat stress yang mempengaruhi tingkat metabolisme, tingkat pemanfaatan pakan dan persaingan ruang antar udang dalam mendapatkan makanan yang meningkat (Hidayat et al.,2014).

Berbeda dengan tingkat kelangsungan hidup, aplikasi bioflok berpengaruh nyata terhadap laju pertumbuhan rata rata spesifik harian, pertambahan panjang serta tingkat efisiensi pakan udang windu $(\mathrm{p}<0,05)$. Laju pertumbuhan rata rata spesifik harian dan pertambahan panjang rata-rata tertinggi terdapat pada perlakuan $\mathrm{C}$ yaitu masing-masing sebesar $1,48 \pm 0,041 \% /$ hari dengan tingkat efisiensi pakan tertinggi terdapat pada perlakuan D yaitu sebesar 47,43 $\pm 7,62 \%$.

Hasil yang sama juga ditunjukkan oleh Husain et al. (2014) yang melaporkan bahwa ikan nila yang dikultur dengan teknologi bioflok memiliki pertumbuhan yang lebih cepat dibandingkan pertumbuhan ikan tanpa perlakuan bioflok. Pertumbuhan lebih cepat dikarenakan semakin banyak jumlah karbon yang ditambahkan ke wadah pemeliharaan, sehingga bakteri dapat tumbuh dengan jumlah yang melimpah, dan digunakan sebagai sumber protein. Ketersediaan bioflok dalam wadah pemeliharaan udang dapat dimanfaatkan sebagai makanan tambahan sehingga mencukupi kebutuhan nutrisi udang. Effendie (2002) menjelaskan pertumbuhan udang meningkat apabila terdapat kelebihan input energi dan protein (asam amino) yang berasal dari makanan.

Widanarni et al, (2008) juga menyatakan bahwa efisiensi pemanfaatan pakan pada perlakuan dengan aplikasi bioflok lebih tinggi. Hal ini disebabkan adanya peningkatan biomassa bioflok sebagai sumber nutrisi atau makanan tambahan bagi biota. Pada umumnya udang windu mendapatkan pertumbuhan optimum dengan pemberian pakan yang mengandung 30$60 \%$ protein (Ebeling et al., 2006). Semakin tinggi nilai efisiensi pakan membuktikan pemanfaatan pakan semakin baik (Kordi, 2010). De Schryver \& Verstraete (2009) menyatakan bahwa untuk menghasilkan $1 \mathrm{~kg}$ biomass ikan pada budidaya tanpa teknologi bioflok memerlukan pakan sebanyak 2,2 kg, sedangkan pada budidaya dengan aplikasi teknologi bioflok hanya membutuhkan $1,3 \mathrm{~kg}$ pakan.

Aplikasi bioflok mampu menekan kadar amoniak dalam air. Hal ini terlihat dari rendahnya kadar amoniak pada perlakuan B dibandingkan dengan perlakuan A di masa akhir pemeliharaan. Kadar amoniak pada perlakuan B yaitu 0,1772 mg/L, sedangkan pada perlakuan A (kontrol) yaitu 0,2862 mg/L. Hal ini senada dengan penelitian Husain et al. (2014) yang mengungkapkan adanya penurunan kadar amoniak pada media pemeliharaan ikan nila merah (Oreochromis niloticus) yang dibudidaya dengan sistem bioflok. Rendahnya nilai amoniak disebabkan peran bakteri heterotof yang mengubah amoniaknitrogen menjadi sumber nutrisi pembentukan biomassa sel (Azim dan Little, 2008).

Nilai parameter kualitas air lainnya yang meliputi suhu, $\mathrm{pH}$, oksigen terlarut, nitrat dan nitrit masih berada dalam ambang batas optimum untuk pemeliharaan benih udang windu. Udang windu memiliki kisaran toleransi suhu yang lebar dibandingkan dengan jenis udang lainnya. Pillay \& Kutty (2005) menyatakan bahwa kisaran toleransi optimum untuk pemeliharaan udang windu berkisar $12^{\circ} \mathrm{C}$ sampai $37,5^{\circ} \mathrm{C}$. Walaupun demikian suhu yang terlalu tinggi dapat menggangu pembentukan flok di media (De Schryver \& Verstraete, 2009).

Oksigen terlarut merupakan salah satu parameter yang penting diperhatikan dalam media pemeliharaan udang windu menggunakan aplikasi bioflok. Aerasi digunakan untuk menjaga agar nilai oksigen terlarut tetap berada pada kisaran optimum. Selain itu, Hargreaves (2013) menyatakan bahwa dalam sistem bioflok, aerasi juga dibutuhkan guna proses pengadukan air dan mencegah terjadinya pengendapan bioflok, sisa pakan dan feses ikan yang dapat berakibat pada meningkatnya amoniak. Kandungan amoniak dalam media pemeliharaan ikut dipegaruhi oleh nilai pH. Ebeling et al. (2006) 
menambahkan bahwa $\mathrm{pH}$ merupakan salah satu parameter yang mempengaruhi tingkatan amoniak terionisasi dan amoniak tak terionisasi didalam air.

Menurut Taslihan et al. (2003) kandungan maksimum nitrit yang disarankan untuk pemeliharaan udang windu adalah 0,2 $\mathrm{mg} / \mathrm{L}$. Hasil penelitian menunjukkan bahwa perlakuan dengan menggunakan aplikasi bioflok menunjukkan kisaran kandungan nitrit yang disarankan dibandingkan dengan perlakuan kontrol. Kandungan nitrit yang tinggi pada beberapa perlakuan bioflok, umumnya terjadi pada saat awal masa pemeliharaan dimana flok belum terbentuk secara optimal. Menurut Fast \& Lester (1992) kandungan nitrat akan menjadi toksik apabila melebihi 1 mg/L. Kandungan nitrat dalam media pemeliharaan berasal dari proses nitrifikasi nitrit menjadi nitrat oleh bakteri nitrifikasi (Sticney, 2005). Rendahnya kandungan nitrit pada perlakuan bioflok menurut Ebeling et al. (2006) disebabkan oleh pemanfaatan nitrit dan nitrat tersebut oleh micro alga sebagai sumber nutrien untuk pertumbuhannya.

\section{Simpulan}

Padat tebar optimal pemeliharaan benih udang windu dengan menggunakan sistem bioflok adalah 15 ekor/10 liter air. Aplikasi bioflok memberikan pengaruh signifikan terhadap pertambahan panjang, laju pertumbuhan rata-rata spesifik harian, dan efisiensi pakan selama masa pemeliharaan benih udang windu. Nilai pertambahan panjang dan laju pertumbuhan spesifik

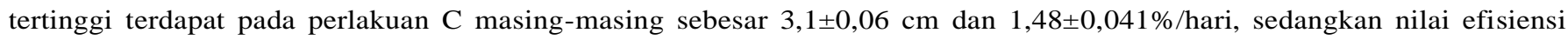
pakan tertinggi terdapat pada perlakuan D yaitu sebesar 47,43 $\pm 7,62 \%$. Aplikasi bioflok tidak berpengaruh signifikan terhadap kelangsungan hidup benih udang windu.

\section{Daftar Pustaka}

Abulias MN, Utarini SR, Winarni ET. (2014). Manajemen Kualitas Media Pendederan Lele Pada Lahan Terbatas Dengan Teknik Bioflok. Jurnal MIPA, 37 (1): 16-21

Afrianto, E dan Liviawaty E. (2005). Pakan Ikan. Kanasius. Yogyakarta.

Asep S, Ikhsan K, Fajar A. (2013). Pemanfaatann bioflok dari media pendederan untuk pemeliharaan larva udang galah (Macrobrachium rosenbergi). Widyariset, 16 (2): 277-282.

Avnimelech Y. (2009). Biofloc Technology, A Practical Guide Book. World Aquaculture Society. Baton Rouge, Louisiana, Amerika Serikat.

Azim ME dan Little DC. (2008). The Biofloc Technology (BFT) In Indoor Tanks: Water Quality, Biofloc Composition, and Gowth and Welfare of Nile Tilapia (Oreochromis niloticus). Aquaculture, 283: 29-35.

De Schryver P. \& W. Verstraete. (2009). Nitrogen Removal from Aquaculture Pond Water by Heterotrophic Nitrogen Assimilation in Lab-Scale Sequarcing Batch Reactors. Biorecource Technology 100: 1162-1167.

Food and Agriculture Organization. (2008). Cultured aquatic species information programme Panaeus monodon (Fabricius, 1798). http://www.fao. org/fishery/culturedspesies/Panaeus monodon/en. [11 Desember 2008].

Hargreaves JA. (2013). Biofloc production system for aquaculture. Southern Regional Aquaculture Center. Publication factual sheet No: $4503.12 \mathrm{pp}$.

Husain N, Putri B, Supono. (2014). Perbandingan Karbon Dan Nitrogen Pada Sistem Bioflok Terhadap Pertumbuhan Nila Merah (Oreochromis Niloticus). Jurnal Rekayasa dan Teknologi Budidaya Perairan, 3 (1): 343-350.

Ebeling JM, Timmons MB, and Bisogni JJ. (2006). Engineering Analysis of the Stoichiometry of Photoautotrophic, Autotrophic and Heterotrophic Removal of Ammonia-Nitrogen in Aquaculture System. Aquaculture, 257: $346-358$.

Effendie MI. (2002). Biologi Perikanan. Yogyakarta. Penerbit Yayasan Pustaka Nusantara. 163 hlm.

Fast AW \& Lester LJ. (1992). Marine Shrimp Culture: Principles And Practices. Amsterdam. Elsevier Science Publisher. 866 pp.

Kementrian Kelautan dan Perikanan. (2012). SDM dan IPTEK Kunci Sukses Industrialisasi Berbasis Perikanan Budidaya. Jakarta: Kementerian Kelautan dan Perikanan.

Kordi MGH. (2010). Budidaya Ikan Nila di Kolam Terpal. Yogyakarta. Lily publisher. 171 hlm.

Pillay TVR \& Kutty MN. (2005). Aquaculture: principles and practices. Second edition. Iowa - USA. Blackwell Publishing. $640 \mathrm{pp}$

Prihantoro AC, Sri W, Yudha TA, Rara D, Wardiyanto. (2014). Pengaruh Padat Tebar Terhadap Pertumbuhan dan Kualitas Udang Windu (Penaeus Monodon) Pada Sistem Nurseri. Aquasains: 253-258.

Stickney RR. (2005). Aquaculture: An Introductory Text. Massachusetts. CABI Publication. 265 pp.

Taslihan A, Supito, Sutikno E, Callinan RB. (2003). Tiger Prawn Culture Technique. Jepara. Direktorat Jenderal Perikanan Budidaya, Balai Besar Pengembangan Budidaya Air Payau. $59 \mathrm{pp}$

Utarini SR, ET. (2014). Manajemen kualitas media pendederan lele pada lahan terbatas dengan teknik bioflok. Jurnal MIPA 37 (1):16-21.

Widanarni, Sukenda, Setiawati M. (2008). Bakteri Probiotik Dalam Budidaya Udang: Seleksi, Mekanisme Aksi, Karakterisasi, dan Aplikasinya Sebagai Agen Biokontrol. Jurnal lmu Pertanian Indonesia, 13 (2): 80-89 